\title{
Threat to marine science lessens
}

The new draft of the Law of the Sea Treaty has eased potential restrictions on international marine research. But not all nations are entirely happy with the result. David Dickson reports from New York

PRESSURE coming largely from the US scientific community has resulted in a number of changes in the proposed Law of the Sea Treaty, under debate in the United Nations since the early 1970 s. The changes are aimed at easing potential restrictions on the conduct of scientific research in regions of the oceans directly controlled by coastal states.

Few of those involved in the negotiations are entirely happy with the outcome. Many nations with large off-shore resource deposits - in particular Canada and some of the Latin American states - would have preferred to stay with the strict controls over research initially proposed, while the scientists of other nations would have liked greater movement in the direction of free scientific enquiry.

Both admit, however, that some compromise between the goals of scientific inquiry and the political and commercial demands of resource management has become necessary. And the changes which have been introduced into a new draft of the treaty, approved at the end of a negotiating session in New York earlier this month, will go to Geneva in the summer for what is hoped to be the final meeting before the treaty is agreed and signed early next year.

Earlier drafts proposed giving coastal states almost absolute authority over research carried out in waters under their control had brought strong protests from scientists who claimed that this would be a direct restriction to the freedom of scientific inquiry.

One of the strongest criticisms came from the US National Academy of Sciences, whose ocean policy committee issued a statement in 1977 warning that unless changes were made in the draft text, the proposed treaty would "cripple future marine scientific research" critical to the survival of the oceans and of mankind.

Since then, the treaty's provisions have been modified as negotiators have attempted to tread a delicate path between commercial and scientific interests, the two connected by the fact that information about resource deposits - for example oil and natural gas - can have important commercial implications when licensing or exploration rights are being considered.

At an early stage, for example, the US dropped its demands that one guiding principle should be the "obligations" of nations to provide for the interests of scientific researchers. It has now been accepted that research within a 200 -mile economic zone and on the continental shelf can only be carried out with the consent of the coastal state, but with the understanding that such consent must be granted when the research project is conducted for peaceful purposes and fulfills other specified criteria.

There have also been modifications to the rules governing the publication of research findings. Previously these would have been strictly controlled by the coastal states involved, triggering complaints of potential censorship. Now the conditions under which permission to publish can be refused have been tightly specified, and a researcher must be told of these conditions before his project begins.

Tentative agreement on the three main outstanding issues of interpretation was reached during the New York negotiations, based largely on proposals put to a working committee by its chairman Dr Alexandrov Yankov of Bulgaria, which the US delegation had already indicated it was prepared to support.

Firstly, there was agreement that disputes over the withholding of consent should be referred to compulsory conciliation, where previously there had been no scope for such a decision to be appealed.

There was also agreement that if a coastal state considers that research to which it has given its consent is carried out in a way that violates the treaty, it now has to give the research worker time to amend the procedures, and no longer has the power summarily to terminate the research project.

Finally, the new draft contains revised wording about the conditions under which a coastal state with a wide continental shelf can refuse permission for research in areas of the shelf outside the 200-mile limit otherwise agreed as the limit of economic responsibility.

Here the wording finally agreed was that permission to carry out research could only be refused in situations where detailed exploitation or exploratory operations were already occurring, or were about to occur within a reasonable period of time.

Negotiators in New York spent considerable time over the wording of this paragraph, since ambiguity over the meaning of "detailed" exploration left a number of countries unhappy that, unless test drills were virtually in place, they could not deny scientists access to areas in which commercially valuable deposits might lie.

Indeed, in the final plenary session of the New York meeting the Canadian delegate argued that the conference might be building "potentially serious interpretation problems" into the proposed treaty with such wording, adding that "my delegation would have much preferred a solution with more specific concrete provisions clearly affirming the rights of coastal states relating to the conduct of marine scientific research on the continental shelf beyond 200 miles."

But US scientists who, with colleagues from the Federal Republic of Germany, have been pushing strongly to ease the initial restrictions, feel that the changes have made the treaty, if not better, at least less unacceptable than previously.

"We still do not feel that the deal on scientific research is as good as it should be," says Dr John Knauss, Dean of Oceanography at the University of Rhode Island. But he adds: "It's now a question of whether we have a treaty with these admendments or no treaty at all'". Others feel that, although the scientific community is unlikely to back the treaty actively, it is also unlikely to oppose it in its present form.

Despite agreement in New York on almost $90 \%$ of the proposed text for the Final Law of the Sea, some major problems remain before the treaty can be signed. One of the largest is the composition of the council for the International Sea-Bed Authority responsible for allocating mining rights and determining the conditions under which resources can be exploited.

Here the developed countries, keen that the activities of their industries should experience minimal restrictions, are urging that only five of the council's 35 members should be able to prevent a mining contract from being refused - in other words, should have power to grant a contract. (Five of the western developed countries US, Japan, West Germany, France and the UK - would have seats on the council.)

In contrast, the developing countries are arguing that it would be more democratic for nine votes to be required for a contract to be awarded, and that a similar number would also be sufficient to block the award of a contract, numbers which the western countries feel could throw them in to an uncomfortable alliance with the Soviet-bloc.

Despite such disagreement, UN officials still hope that sufficient progress has been made to conclude the final version of the treaty during the Geneva meeting, and for it to be signed next spring. The next problem will be getting it accepted. And in the US this means convincing the Senate, responsible for ratifying all foreign treaties, that the changes have been sufficient to meet the previously expressed concerns. 